\title{
Assessment of the Potential for Spread of Deadly Ebola Virus across International Borders by Returnee Travelers and Humanitarian Health Workers from West Africa
}

\author{
Vincent Icheku \\ School of Health and Social Care, London South Bank University, 103 Borough Road, London SE1 OAA
}

Copyright $(\subseteq 2015$ Horizon Research Publishing All rights reserved.

\begin{abstract}
The recent Ebola Virus Disease (EVD) outbreak in West Africa is so far the largest and deadliest in recorded history. The rapid spread of the disease in the region and its potential for international spread prompted the World Health Organization to declare the outbreak a public health emergency of international concern. [1] This paper assesses the potential for the spread of the disease across international borders by returnee travelers and humanitarian health workers, given that the disease spreads through physical contact. The surveillance data published by both the World Health Organization (WHO) and Centers for Disease Control and Prevention (CDC) were reviewed to identify the EVD epidemiological situation in West Africa from March 2014 to September 2014. The risk assessment data published by Public Health England (PHE) and CDC travel updates were reviewed to identify travel group(s) most at risk of transmitting EVD across international borders. Studies focusing on West African cultural practices were also reviewed to identify aspects that carry risk of EVD transmission. The study found that the risk of travelers transmitting EVD across international borders is low and would remain so on two conditions. First, all travelers must avoid direct physical contact with a sick or dead person or animal infected with EVD. Second, international humanitarian health workers in affected areas of West Africa who will eventually return to their home countries must work in safe environments with adequate protective equipment. The risk of travelers acquiring EVD is considered very low, yet there is serious concern that the disease may spread further within West Africa and across international borders. Local burial practices exacerbate the disease spread while poor working environments and inadequate supply of equipment increase risk of exposure to EVD of humanitarian workers. This researcher recommends addressing the issues through local awareness, pre-travel advice and capacity investment in the healthcare infrastructure in the EVD affected areas.
\end{abstract}

Keywords Ebola Virus Disease, EVD, Burial Practices, Humanitarian Health Workers, VFR travelers, Viral Haemorrhagic Fever, Zoonotic

\section{Introduction}

\section{What is Ebola?}

Ebola Virus Disease (EVD) belongs to a group of viral haemorrhagic fever (VHF) caused by several distinct families of viruses: the arena-viruses, bunya-viruses, filo-viruses, and flavi-viruses. EVD is one of two members of the filovirus family along with Marburg virus. EVD comprises of five distinct species named mainly after where they were originally found: Bundibugyo ebolavirus (BDBV); Zaire ebolavirus (EBOV); Reston Ebola Virus (RESTV); Sudan ebolavirus (SUDV); and Taï Forest ebolavirus (TAFV). BDBV, EBOV, and SUDV have been associated with large EVD outbreaks in Africa, whereas RESTV and TAFV have not. [2]EVD first appeared in Zaire (now the Democratic Republic of Congo) in 1976 in a Yambuku village situated near the Ebola River from which the disease got its name. The outbreak of Ebola virus in Zaire was blamed for the 280 deaths out of 318 cases of a haemorrhagic fever reported in Zaire in 1976. In the same year 156 people died out of 284 cases reported in Sudan. [2]

\section{Infection and Transmission}

The African fruit bats are believed to be the natural hosts of EVD and transmitted to intermediate hosts land mammals such as monkeys, apes, or pigs through bats drop or partially eaten fruits and pulp or direct contact with saliva or faeces of the natural host. This chain of events forms a possible means of transmission to human through contact with the natural or intermediate hosts' populations. Many people become infected with EVD through contact with infected animals, 
either in the process of slaughtering or through consumption of blood, milk, or raw or undercooked meat.

The disease then passed from human to human through direct contact through broken skin or mucous membranes or blood, secretions or other bodily fluids of infected persons, or from contact with contaminated needles or dead bodies of humans and animals. [3] For example, cultural practice practices in African allow for burial ceremonies in which mourners have direct contact with the body of the deceased person, which often result in the dead bodies of infected persons with EVD infecting the living with the disease. Similarly, health-care workers have frequently been infected while caring for EVD patients particularly those in resource poor settings with inadequate infection control equipment. [4, 5]

\section{Signs and Symptoms of EVD}

EVD has a case fatality rate of up to 90 percent. [5] A case fatality rate (CFR) or case fatality risk is a property of an infectious disease in a particular population which states the risk of fatality due to the disease per case. [6] This means that EVD has a very high mortality rate with poor prognosis. Laboratory tests have shown that the few people that survived have good immune response and subsequently develop antibodies against the disease that last for at least 10 years. [7] However, people who survived from the disease can still transmit the virus through their semen for up to 7 weeks after recovery from their illness. [8] These make EVD one of the world's most deadly diseases and a highly infectious virus. [1]

Signs and symptoms of EVD are characterised by severe acute viral illness often characterised by the sudden onset of fever, intense weakness, muscle pain, headache, nausea and sore throat. This is followed by vomiting, diarrhea, impaired kidney and liver function, and in some cases, both internal and external bleeding. Infected people remain infectious as long as their blood and body fluids, including semen and breast milk, contain the virus. [5, 9]

\section{Ebola Outbreaks in West Africa}

As of September 2014, when this paper was completed and ready for publication an epidemic of the EVD is ongoing in West Africa, a sub region of Africa consisting of seventeen countries. The countries are Benin, Burkina Faso, island of Cape Verde, Gambia, Ghana, Guinea, Guinea-Bissau, Ivory Coast, Liberia, Mali, Mauritania, Niger, Nigeria, island of Saint Helena, Senegal, Sierra Leone, and Togo. [10] The outbreak which started in Guinea in March 2014 has now spread to Liberia, Sierra Leone, Nigeria and Senegal and considered to be the most severe outbreak of the disease since its discovery 1976. [11, 12]

To create the fullest possible picture of the unfolding epidemic, table 1-5 were constructed using surveillance reports published by both the World Health Organisation (WHO) and Centers for Disease Control and Prevention (CDC). The primary sources of the information contained in the reports are from the affected countries' health ministries. $[11,13$,$] The aim of the tables below is to give readers$ visualised illustration of the current EVD epidemiological situation in West Africa since the first outbreak in March 2014 to September 2014; based on four main themes:

1) Total initial and cumulative number of suspected and confirmed cases

2) Total initial and cumulative number of deaths, and

3) Percentage of initial and cumulative case fatality rate.

4) Areas of reported outbreaks

The total initial and cumulative numbers of suspected and confirmed cases provide data on initial case(s) and localised transmission as at the month of first reported case(s) and cumulative number of case(s) as at September 2014. The total initial and cumulative number of deaths provides data on initial reported death(s) as at the month of first reported death(s) and cumulative number of death(s) as September 2014. The areas of reported outbreak by each country in databases provided to the WHO and CDC from March to September, 2014. [11]

The WHO in the case definitions for EVD's document, defines a suspected case as an illness in any person, alive or dead, who has (or had) sudden onset of high fever and had contact with a person with a suspected, probable, or confirmed Ebola case or with a dead or sick animal; any person with sudden onset of high fever and at least three of the following symptoms: vomiting, anorexia, headache, loss of appetite, diarrhea, lethargy, stomach pain, aching muscles or joints, difficulty swallowing, breathing difficulties, or hiccupping; or any person who had unexplained bleeding or who died suddenly from an unexplained cause. A confirmed case on the other hand, is when a sample from a person was positive for EVD in laboratory testing. The case fatality rate (CFR) is defined as the proportion of reported cases of a specified disease or condition which are fatal within a specified time. It is calculated as the percentage of fatal EVD cases among reported cases and used in the tables below to demonstrate the severity of the EVD outbreak in West African. [14]

\section{Guinea}

Ebola virus became a major public health issue in sub-Saharan Africa since its discovery in 1976 but no cases of the disease had ever been reported in West Africa. The first official acknowledgement of outbreak of Ebola virus in West Africa was on the 23 March 2014 when The Ministry of Health $(\mathrm{MoH})$ of Guinea notified WHO of a rapidly evolving outbreak of the disease. [11, 12] However, the first outbreak of the disease was traced to a two-year old child who died in December, 2013, in the village of Meliandou, Guéckédou Prefecture, south eastern part of Guinea. The boy's mother, sister, and grandmother later became ill with similar symptoms and also died. [15] As the data in table 1 below suggests, other people infected by the boy and his family spread the disease to other villages and districts. 
Table 1. Cases of EVD in the month of outbreak in Guinea and cumulative cases up to September 2014

\begin{tabular}{|c|c|c|c|c|}
\hline & $\begin{array}{l}\text { Guinea's suspected and } \\
\text { confirmed cases of EVD }\end{array}$ & Total (deaths) & $\begin{array}{c}\text { Case fatality rate } \\
(\%)\end{array}$ & $\begin{array}{c}\text { Areas of reported } \\
\text { outbreaks }\end{array}$ \\
\hline $\begin{array}{c}\text { Initial case(s) and } \\
\text { localised transmission as } \\
\text { at month (March) of first } \\
\text { reported }\end{array}$ & 112 & 70 & 62.5 & $\begin{array}{c}\text { First reported: in the } \\
\text { village of Meliandou, } \\
\text { south-eastern of } \\
\text { Guinea }\end{array}$ \\
\hline $\begin{array}{l}\text { Cumulative number of } \\
\text { cases(September 2014) }\end{array}$ & 771 & 494 & 64 & $\begin{array}{c}\text { Spread to:Conakry, } \\
\text { Coyah, Forecariah, } \\
\text { Gueckedou, } \\
\text { Kouroussa, Macenta, } \\
\text { Siguiri, Pita, } \\
\text { Nzerekore, Dubreka, } \\
\text { Yomou, Kerouane } \\
\\
\text { No longer active: } \\
\text { Boffa, Dabola, } \\
\text { Dinguiraya, } \\
\text { Kissidougou, } \\
\text { Telimele }\end{array}$ \\
\hline
\end{tabular}

Table 1 also shows that the initial case and localised transmission as at the month (March) of first reported case was 112 case and 70 deaths in the Guinea district Guéckédou. As at September 2014, EVD had spread from the epicenter of Guéckédou district to many other districts, killing 494 out of 171 suspected and confirmed cases. Although, EVD is no longer active in some areas such as Boffa, Dabola, Dinguiraya, Kissidougou, Telimele but continues to affect other areas, including Conakry, Coyah, Forecariah, Gueckedou, Kouroussa, Macenta, Siguiri, Pita, Nzerekore, Dubreka, Yomou and Kerouane. [11]

Guinea, the country that first reported cases of EVD in March, 2014 and by September 2014 reported a case fatality rate of 64 percent. The increase in CFR from 62.5 in March, the month of first reported cases, to 64 percent in September, seven months later, is in no doubt a country with increasing number deaths from EVD. [11, 16]

\section{Liberia}

Table 2. Cases of EVD in the month of outbreak in Liberia and cumulative cases up to September 2014

\begin{tabular}{|c|c|c|c|c|}
\hline & $\begin{array}{c}\text { Liberia's suspected and } \\
\text { confirmed cases of EVD }\end{array}$ & Total (deaths) & $\begin{array}{c}\text { Case fatality rate } \\
(\%)\end{array}$ & $\begin{array}{c}\text { Areas of reported } \\
\text { outbreaks }\end{array}$ \\
\hline $\begin{array}{c}\text { Initial case(s) and } \\
\text { localised transmission as } \\
\text { at month (March) of first } \\
\text { reported }\end{array}$ & 7 & 2 & 28.5 & $\begin{array}{c}\text { Foya district, Lofa } \\
\text { County }\end{array}$ \\
\hline $\begin{array}{c}\text { Cumulative number of } \\
\text { cases(September 2014 }\end{array}$ & 1698 & 871 & 51 & $\begin{array}{c}\text { Lofa, Montserrado, } \\
\text { Margibi, Bomi, Bong, } \\
\text { Grand Cape Mount, } \\
\text { Nimba, Grand Bassa, } \\
\text { Grand Gedeh, } \\
\text { RiverCess, River Gee, } \\
\text { Sinoe, Gbarpolu }\end{array}$ \\
\hline
\end{tabular}

An outbreak of Ebola has been ongoing in Liberia since 13 March, the World Health Organisation $[11,16]$ surveillance data in table 2 shows that the outbreak had reached Liberia as at 29 March 2014. The table shows that 2 out of the 7 suspected cases from Foya district and Lofa County died in March. As at September 2014, EVD had spread from Foya district to many other districts, killing 871 out of 1698 suspected and confirmed cases. The case fatality ratio of 51 percent in September 2014, compared to 28.5 in March, makes Liberia one of the countries in West Africa with highest number of cases and deaths from EVD, surpassed on by Guinea. [11, 16]

The Liberian government in response to the outbreak implemented new travel policies aimed at preventing the spread of the disease. The policies include among other things closures of all borders except major entry points (Roberts International Airport, James Spriggs Payne Airport, Foya Crossing, Bo Waterside Crossing, and Ganta Crossing) and also screening at the entry points that remain open. This new travel policy affected both incoming and outgoing travellers. [17] The spread of EVD continued into border districts and subsequently into neighbouring Sierra Leone despite all the travel restrictions. [11, 16] 


\section{Sierra Leone}

Table 3. Cases of EVD in the month of outbreak in Sierra Leone and cumulative cases up to September 2014

\begin{tabular}{|c|c|c|c|c|}
\hline & $\begin{array}{c}\text { Sierra Leone's suspected and } \\
\text { confirmed cases of EVD }\end{array}$ & Total (deaths) & $\begin{array}{c}\text { Case fatality rate } \\
(\%)\end{array}$ & $\begin{array}{c}\text { Areas of reported } \\
\text { outbreaks }\end{array}$ \\
\hline $\begin{array}{c}\text { Initial case(s) and } \\
\text { localised transmission as } \\
\text { at month (May) of first } \\
\text { reported }\end{array}$ & 2 & 2 & 100 & $\begin{array}{c}\text { First affected area was } \\
\text { Kailahun district }\end{array}$ \\
\hline $\begin{array}{c}\text { Cumulative number of } \\
\text { cases(September 2014 }\end{array}$ & 1,216 & 476 & 39 & $\begin{array}{c}\text { Kailahun, Kenema, } \\
\text { Kono, Kambia, } \\
\text { Bombali, Tonkolili, } \\
\text { Port Loko, Pujehun, } \\
\text { Bo, Moyamba, } \\
\text { Bonthe, Western area }\end{array}$ \\
\hline
\end{tabular}

Although several suspected cases of EVD in Sierra Leone were reported in March and April 2014, they proved to be Lassa fever and other more common illnesses. [11] The first official outbreak of EVD in Sierra Leone was reported in late May, 2014 on the border of district of Kailahun. The 2 initial suspected cases, both of whom died had travelled to Guinea before onset of their illness. Table 3 shows that the 2 initial case and localised transmission in the border district of Kailahun died. As at September 2014, EVD had spread to districts such as Kenema, Kono, Kambia, Bombali, Tonkolili, Port Loko, Pujehun, Bo, Moyamba, Bonthe, rural and urban Western areas (including the capital of Freetown) killing 476 people out of the 1.216 suspected cases. [11, 16]

The Government response to the outbreak is to implement travel restrictions in and out of the country. Quarantine measures for communities affected by Ebola; travel in and out of those communities are restricted until a medical team clears them. The Government instituted new protocols for arriving and departing passengers at Lungi International Airport; restrictions on public and other mass gatherings and authorized police and military personnel to help enforce these and other prevention and control measures. [18] The reduction of case fatality rate from 100 percent in May to 39 percent in September 2014 shows that the preventive measures taken by the Sierra Leonean Government yielded good result. $[11,16]$

\section{Nigeria}

Table 4. Cases of EVD in the month of outbreak in Nigeria and cumulative cases up to September 2014

\begin{tabular}{|c|c|c|c|c|}
\hline & $\begin{array}{c}\text { Nigeria's suspected and } \\
\text { confirmed cases of EVD }\end{array}$ & Total (deaths) & $\begin{array}{c}\text { Case fatality rate } \\
(\%)\end{array}$ & $\begin{array}{c}\text { Areas of reported } \\
\text { outbreaks }\end{array}$ \\
\hline $\begin{array}{c}\text { Initial case(s) and } \\
\text { localised transmission as } \\
\text { at month (July) of first } \\
\text { reported }\end{array}$ & 1 & 1 & 100 & $\begin{array}{c}\text { First outbreak was } \\
\text { reported in the city of } \\
\text { Lagos }\end{array}$ \\
\hline $\begin{array}{c}\text { Cumulative number of } \\
\text { cases(September 2014 }\end{array}$ & 21 & 7 & 33.3 & Lagos \\
\hline
\end{tabular}

The outbreak of EVD in Nigeria was officially announced on July 25, 2014, when the Nigerian Ministry of Health confirmed that a man in Lagos, Nigeria, died from Ebola. The man, Patrick Sawyer, a Liberian-American, had been in a Lagos hospital since arriving at the Lagos airport from Liberia few days earlier. Sawyer potentially exposed many other people, which prompted health experts to describe the spread of Ebola to Lagos, a city of 21 million, as a potential catastrophe. [19]

Table 4 also shows a reduction of case fatality rate from 100 percent in July, the month of first reporting to 33.3 in August 2014. The table also shows that EVD subsequently spread from city Lagos to Port Harcourt and killed 7 percent of those suspected of having the disease. However, the Nigerian government took steps to prevent further spread. The Government's policy of containment by tracing and quarantining suspected cases was very effective and there is no new Ebola case reported in Nigeria since the end of August, 2014. The containment of the outbreak in Nigeria has been confirmed by a recent report from both WHO and CDC. $[11,16]$ 


\section{Senegal}

Table 5. Cases of EVD in the month of outbreak in Senegal and cumulative cases up to September 2014

\begin{tabular}{|c|c|c|c|c|}
\hline & $\begin{array}{c}\text { Senegal's suspected and } \\
\text { confirmed cases of EVD }\end{array}$ & Total (deaths) & $\begin{array}{c}\text { Case fatality rate } \\
(\%)\end{array}$ & $\begin{array}{c}\text { Areas of reported } \\
\text { outbreaks }\end{array}$ \\
\hline $\begin{array}{c}\text { Initial case(s) and } \\
\text { localised transmission as } \\
\text { at month (August) of first } \\
\text { reported }\end{array}$ & 1 & 0 & 0 & $\begin{array}{c}\text { Senegalese capital } \\
\text { Dakar }\end{array}$ \\
\hline $\begin{array}{c}\text { Cumulative number of } \\
\text { cases(September 2014 }\end{array}$ & 0 & 0 & 0 & $\begin{array}{c}\text { Contained in the } \\
\text { capital city of Dakar }\end{array}$ \\
\hline
\end{tabular}

Senegal became the fifth country in West Africa to confirm a case of Ebola. The only case of EVD in Senegal was attributed to a 21-year-old Guinean man, who travelled from his native country to Dakar in mid-August, 2014. The Health Minister, in a news conference stated that the young man, a student arrived from neighbouring Guinea had turned up for treatment at a hospital in the Senegalese capital Dakar. The results of tests carried out by the Pasteur Institute in Dakar for EVD were positive. The Senegal Ministry of Health had been preparing for possible Ebola cases, and health officials were proactive in tracing 67 of the young man's contacts. All of those contacts were monitored and discharged after passing through the 21-days incubation period for EVD. In other words, free from EVD infection. The 21-year-old student eventually recovered and was released from isolation on the September 21, 2014. [20]

In an effort to protect itself from spread of EVD in the country, the Senegalese Government closed its southern land border with Guinea. It also banned flights to and from Sierra Leone, Liberia and Guinea, but not Nigeria. The Government took the decision despite warning from the World Health Organisation that such measures could be counterproductive. [21] The closure of its borders with Guinea did not stop people travelling across the border to its cities, which are major trade and transport hubs. [22] However, the zero suspected case and death rates as shown in table 5 is indicative of successful preventive steps taken by the Senegalese Government.

The above tables $1-5$ show a striking difference of CFR amongst the 5 countries (Guinea, Liberia, Sierra Leone, Senegal and Nigeria). This might be the result of differences in health care infrastructure in the five countries. For example, the most severely affected countries, Guinea, Sierra Leone and Liberia, have many things in common. They all have very weak health care facilities, lacking in human and infrastructural resources, having only recently emerged from long periods of civil unrest and conflict. They are poor countries with limited expenditure for health care. In 2012, for instance, Guinea had a total population of about 11.5 million and its total expenditure on health as percentage of Gross Domestic Product (GDP) was 6.3. [23] In the same year, Liberia with total population of about 4.2 million, total expenditure on health as percentage of Gross Domestic Product (GDP) amounted to 15.5. [24] Sierra Leone's total expenditure on health as percentage of Gross Domestic Product (GDP) amounted to 15.1 with a total population of about 5.9 million in the same year. [25]

The public health infrastructures of the countries are in a poor state with very low doctor-to-patient ratios. Liberia, for example, has one doctor for every 100,000 people. Consequently, the strain that the Ebola outbreak has placed on an already weak health care system means that the system cannot respond effectively; there is not enough proper medical equipment, trained medical professionals or space to isolate those infected. Hospitals and treatment centers are forced to turn away patients, who return home and risk infecting their family and friends. [26] Unlike, the three countries, (Guinea, Sierra Leone and Liberia) with depleted health care infrastructure, Senegal and Nigeria considered low-income or low-middle income countries with relatively in-tact health system still in place fared better. This is evident in the ability of the two countries, Nigeria and Senegal, to put the outbreak of EVD under control, respectively. [19] As illustrated in the table 5, only one case of EVD was confirmed in Senegal in August 2014 and the man survived. No new case of EVD has been reported in Nigeria since August. 31, 2014, suggesting that the outbreak has been contained. [16, 27]

However, one thing is common in the experience of the 5 countries. The EVD spread across the countries' borders is through travel; starting in Guinea then spreading across land borders to Liberia, Sierra Leone, and Senegal and by air only to Nigeria. [5] International travel for holiday, business and VFR travels has been on the increase from 528 million in 1995 to 1,087 million in 2013. Africa on its own grew from 18.7 million in 1995 to 55.8 million in 2013. Growth is expected to continue in 2014 at a sustained rate of 4.0 percent to 4.5 percent worldwide. Africa is expected to grow from 4 percent to 6 percent. [28] These statistics show that international travel is common with potential for travel to Central Africa and West Africa areas where EVD is endemic.

The EVD transmission rate through close contact in West Africa is progressing at an alarming rate and is considered an international health threat, [1] yet the literature search conducted for this study could not find any study that focuses on risk of transmitting the disease across international borders by returnee travelers and humanitarian health workers who may be exposed to the disease in the region. 


\section{Rationale for This Study}

This researcher is a UK resident and was in Nigeria when the first death from EVD was reported in Lagos. The fear of the disease spreading within Lagos - a densely populated city of about 21 million people - and in Nigeria, the biggest economy in Africa with an estimated 170 million people, was overwhelming. Health workers, some of whom later died from the disease, were understandably afraid of what it means and of the implications for them as practitioners. [29]

On return to Europe, the researcher observed similar panic and fear about how far the epidemic could spread outside of West Africa. The poor level of knowledge amongst policy makers and healthcare professionals is disturbing. This has spawned a number of false alarms in many countries. Many people have gone to hospitals with Ebola-like symptoms, only to test negative. Planes have been held on the runways and travelers quarantined because of scares that were ultimately debunked. [30] Many of the actions were in response to fear with no scientific basis. This study was, therefore, spurred on by the need to try and embed some rational thinking and greater understanding of how EVD could spread across international borders focusing on travelers and humanitarian health workers returning from West Africa.

\section{Aims}

To assess the potential risks for spreading EVD across international borders by returnee humanitarian health workers and others traveling from West Africa.

\section{Objectives}

To review surveillance data and identify the current EVD epidemiological situation in West Africa

To review literature on types of travel group(s) and identify group(s) most at risk of transmitting EVD across international borders.

To review literature on West African burial practices and identify aspects that carry the risks of EVD transmission.

\section{Methods}

The literature for this review was gathered through searches on the Medical Literature Online (MEDLINE) for the period 2000-2014, Online database Google Scholar and the ProMED database using the keywords 'travel', 'traveler', 'imported' and 'Ebola Hemorrhagic Fever' combined with the terms 'Ebola Virus Disease' and 'EVD'. Also reviewed were the relevant sections of the WHO (www.who.int/en); PHE's National Travel Health Network and Centre (www.nathnac.org); US Centers for Disease Control and Protection (www.cdc.gov); World Tourism Organization UNWTO (http://www.e-unwto.org); and the UK's Public Health England (PHE)

(www.gov.uk/government/organisations/public-health-engl and).
Data on the West African EVD outbreak from the month of first outbreak in individual countries and cumulative cases up to September 2014 was gathered from surveillance reports published by both WHO and CDC. The primary source of the data contained in the reports was from the affected countries' health ministries. [11, 16] International travel data was gathered from UNWTO. Travel group information was gathered from risk assessment data published by PHE and CDC. The general information on travel and cultural practices were obtained from studies mostly published in peer reviewed journals.

\section{Result}

The study found evidence of well-established association between travel and the acquisition or transmission of infectious diseases. Travelers may be exposed to infectious disease depending on their travel destination, the purpose of the visit and presence of infectious agents in the area visited. [31] Findings show that a number of risk factors for acquiring EVD are associated with travel and from endemic areas. [32] In the case of West Africa, the outbreak was first in Guinea and then spread across land borders to Sierra Leone and Liberia, by air to Nigeria, and by land to Senegal. This prompted the CDC to urges all US residents to avoid nonessential travel to Guinea, Liberia, and Sierra Leone and advised those who must travel to those countries to protect themselves by avoiding contact with blood and body fluids of people who are sick with EVD [5]. Both WHO and CDC identified the following types of travelers to West Africa who may be at risks of EVD.

\section{Tourists and Businessmen/Women Returning from Affected Areas in West Africa}

The WHO's view is that the risk of a tourist or businessman/woman becoming infected with EVD during a visit to West Africa and developing the disease after returning to home country is extremely low, even if the visit included travel to the local areas from which primary cases have been reported. This is because transmission of EVD requires direct contact with blood, secretions, other body fluids or organs of infected living or dead persons or animals - all unlikely exposures for the average traveler with this group. This group of travelers is, therefore, advised to avoid all such contacts at all cost. [33]

The risk of travelers acquiring EVD is considered very low and one of the reasons given for this view is that people are often too sick to travel when the illness is a direct result of EVD infection. [33] However, the case of Mr. Sawyer, a traveler from Liberia who brought EVD to Nigeria, shows that there is a possibility that a person who had been exposed to EVD and developed symptoms may board a commercial flight, or other mode of transport, without informing the transport company of his or her EVD status. [34] Fortunately, none of Mr. Sawyer's co-travelers on the flight became 
infected with EVD. This supports the WHO view that the risk of EVD transmission on airplanes is low, which may explain why the organization is not advocating travel bans to and from the affected West African countries. [35]

\section{Humanitarian Health Workers Posted in Affected Areas}

There is a risk of EVD infection for humanitarian health workers and local volunteers, especially if involved in caring for EVD patients [5]. This study found that as of 28 September 2014, a total of 216 heath workers had died from EVD out of 377 confirmed cases. [36, 37] Shortages of personal protective equipment or its improper use and shortage of medical staff for such a large outbreak were found to be the main factors that helped to explain the high proportion of confirmed cases and death rate among the EVD health care workers. [38]

Table 6 shows that of the three main Ebola-affected countries, Liberia has the highest healthcare worker death rate of 95 deaths out of 185 confirm cases. For comparison, Sierra Leone and Guinea's healthcare worker death rate were 81 deaths out of 114 confirm cases and 35 deaths out of 67 confirm cases respectively. [38]

The concern that travelers and humanitarian health workers returning from affected areas in West Africa may be incubating the disease and become infectious after returning to their home countries prompted many countries to impose travel restrictions to or from areas in West Africa where EVD is endemic. However, WHO opposed the travel restrictions on the grounds that they are preventing humanitarian health workers from entering the affected areas resulting in marginalization of the affected population and potentially increasing the spread of the disease. [39]

Quarantine also has been advocated for returnees in some countries. In the United Kingdom, many British nationals returning from West Africa were quarantined in case of EVD infection. After their return they were asked to voluntarily confine themselves at home for 21 days - the maximum incubation period - before contact with others [40]. Unlike UK, many other countries such as Canada, Australia, and some US states imposed mandatory quarantines on humanitarian health workers returning from EVD-endemic areas of West Africa. [41]
In the USA, for instance, Kaci Hickox, an American nurse who was returning after working with Doctors without Borders, was placed in mandatory quarantine but was allowed to return home after she threatened legal action. [42] However, both the United Nations (UN) and the US Federal Government are opposed to such measures. For example, US President Barrack Obama, in a recent press conference, said that subjecting returning humanitarian health workers to mandatory quarantines is motivated by fear, not science, and will be counterproductive because it will dissuade people from joining the fight against the disease in West Africa. On a similar note, the United Nations Secretary-General, Ban $\mathrm{Ki}$-moon, warned that strict restrictions on the movement of health workers who have been fighting the deadly Ebola virus in West Africa is absolutely unnecessary. [43] These views are compatible with the decision of an American judge who rejected a State Authority's bid to enforce the mandatory quarantine order on Kaci Hickox. The judge set aside the order on the grounds that court is fully aware of the misconceptions, misinformation, bad science, and bad information being spread from shore to shore with respect to Ebola. [42]

A travel history is a key factor in the assessment of the returning traveler; the incubation period and symptoms of individual EVD infections should be taken into account. EVD presents itself after the incubation period with sudden onset of fever, headache, joint and muscle aches, and weakness. As the infection progresses, nausea, shock, shortness of breath, confusion, and hemorrhage can occur, which often lead to multi-organ failure, vomiting and diarrhea. [44] Travelers still in the endemic areas of West Africa experiencing these symptoms are advised to visit a healthcare provider immediately or find the nearest Embassy or Consular Office that can help them find a healthcare facility in the area, and inform them that they may have had contact with the Ebola virus. They are also advised to limit contact with others and avoid all other forms of travel. [45] In addition, isolation and contact tracing is recommended by WHO to prevent further EVD transmission in the returnee's home countries. [38]

Table 6. Ebola virus disease infections in healthcare workers as of 28 September 2014 [38]

\begin{tabular}{|c|c|c|}
\hline Country & Confirmed cases & Deaths \\
\hline Guinea & 67 & 95 \\
\hline Liberia & 185 & 5 \\
\hline Nigeria & 11 & 81 \\
\hline Sierra Leone & 114 & 216 \\
\hline Total & 377 & \\
\hline
\end{tabular}


If the recommended level of precaution for healthcare settings and protective equipment use is implemented, transmission of EVD should be prevented. Unfortunately, there are little or no EVD prevention and control quality assurance checks available in the three West African countries (Liberia, Sierra Leone and Guinea) most affected by the EVD outbreak. This study found evidence demonstrating that the healthcare systems in the countries were already near collapse due to many years of civil strife and wars. Supply of proper medical equipment is inadequate and there are not enough trained medical professionals or space to isolate those infected. Treatment and care are carried out in some cases in tents and/or makeshift facilities. Hospitals and treatment centers are forced to turn away patients, who then return home and risk infecting their families and friends. [26] The international communities are only just waking up to the crisis and are now making ongoing efforts to ensure the provision of sufficient personal protective equipment to all EVD care settings, along with of trained staff and relevant guidance to minimize exposure of healthcare workers to the EVD infection. [38]

In addition to poor healthcare infrastructure and medical equipment, local burial practices put both national and international healthcare workers at risk of EVD infections. A study, "Cultural Contexts of Ebola in Northern Uganda" following the outbreak there in 2000 , found that that once a person died, his or her paternal aunt was called to wash and prepare the body for burial. If the father did not have a sister, an older woman in the victim's patrilineal kin was asked to prepare the body. Woman generally removed clothes, washed the body, and dressed the body. At the funeral, members of the deceased's family ritually washed their hands in a common bowl and, with an open casket, all were welcome to touch the deceased person on the face or elsewhere in a practice called "love touch". The body was then wrapped in a white sheet or favorite outfit and buried. This explains in part why 67 percent of all presumptive EVD cases in the Uganda study were women. [46]

These cultural practices are no doubt in direct conflict with the procedures healthcare workers are expected follow to minimize the risk that the disease will spread. This may have prompted WHO to establish specific guidelines for healthcare workers on how to safely transport and bury EVD victims. The guideline includes instructions to be aware of the deceased's family's cultural practices and religious beliefs and to provide supportive information that would help the family understand why some practices cannot be done because they place the family or others, including healthcare workers, at risk of EVD infection. [47]

\section{Visiting families and relatives}

According to UK's Health Protection Agency, now part of Public Health England (PHE), the number of travelers visiting families and relatives (VFR) has increased and this often involves travel to regions that have a higher risk of certain infectious diseases. Thus, a disproportionate risk of disease infection falls on people who have undertaken VFR travel. [48] With the current outbreak of EVD in West Africa, travelers visiting for burial of love ones or sick family and relatives in the region may be at high risk of acquiring the disease. [31, 32, 49] A number of risk factors for acquiring EVD during travel have been identified by WHO and CDC: contact with EVD-infected person; direct contact with EVD-symptomatic patients and their bodily fluids; close contact with EVD-infected live or dead animals, corpses and/or bodily fluids from infected deceased patients. Such contact produces high risk of acquiring the deadly disease. $[11,16]$

However, the risk assessment by PHE indicates that the risks of EVD for travelers visiting families and relatives in affected countries is considered low, unless the traveler has direct physical contact with a sick or dead person or animal infected with EVD. [50] As noted earlier, EVD is one of the world's most fatal diseases, highly contagious and caused by zoonotic viral infections transmitted to humans directly through infected humans or animals. [51] It has been established that the time of death from EVD is the time when the person is the most infectious and the viral load is the highest. This prompted WHO officials to report that traditional burial practices in West Africa are among the obstacles that are making it difficult to control the EVD outbreak in the region. [52] In other words, the VFR traveler who comes in physical contact with an EVD-infected person or body is at greatest risk of contracting the disease and may become host for the disease on arrival to his or her home country. Thus, to reduce the number of cases of EVD transmission across international borders from VFR travelers, particular attention needs to be given to pre-travel advice.

\section{Discussion}

This review has been possible because of the current EVD surveillance reports on West Africa published by both the WHO and CDC. The four areas that emerged from the review reports are: total initial and cumulative numbers of suspected and confirmed cases, total initial and cumulative numbers of deaths, percentage of initial and cumulative case fatality rate, and areas of reported outbreaks. $[11,16]$ The subsequent analysis enabled this study to confirm that the current outbreak of EVD in West Africa is the most severe with more cases and deaths than all previous outbreaks put together. [1]

The study was also able to establish that EVD spread between countries starting in Guinea then spreading across land borders to Sierra Leone, Liberia, and Senegal. The EVD spread to Nigeria was by air yet the potential for EVD spreading across international borders through such travel is considered low. [5] This is attributable to the incubation period of EVD, which varies from 2 to 21 days and the 
disease's ability to spread only by direct contact with someone who is showing signs of the disease; the symptoms limit a person's ability to spread the disease as they are often too sick to travel. [53] Thus, the risks of travelers becoming infected with EVD during visits to affected areas in West Africa and transmitting it across international borders is low. $[11,16]$

However, this study also found that burial practices allowing direct physical contact with sick or dead persons infected with EVD remain a threat to travelers visiting the disease-endemic area of West Africa. WHO is quoted as stating that when a person dies from EVD, the body leaks out fluids from every orifice because of failed immune system. The fluid is teeming with high virus load that is very infectious and remains so for three days in the deceased body. [51] One study established that nearly two thirds of cases of Ebola in Guinea during the current outbreak resulted from burial practices. [54] Another study demonstrated that the semen of the few people who survived the disease remains infectious up to 3 months. [55] Thus these remain major factors in the disease transmission.

The VFR travelers who have close physical contact with sick or dead body of loved ones are at risk of infection and subsequent transmission of the disease. The first laboratory-confirmed case of Ebola to be diagnosed in USA was a man who had traveled from Liberia to Dallas, to attend the high school graduation of his son. He apparently contracted the disease while helping an Ebola-infected neighbor in his home country of Liberia. [56] The first laboratory-confirmed case of Ebola to be diagnosed in Nigeria was by a traveler who flew into Nigeria after celebrating Liberia's Independence Day with his family and friends. [34] Both of these cases resulted in fatality. The current efforts by some organizations to conduct public awareness campaigns among the communities in West Africa through social mobilization have not been very successful. [38] This may be because the safe burial methods introduced by the humanitarian organizations are regarded as un-African. African cultures demand that dead bodies must be washed and dressed before burial, so Africans are very reluctant to bury a loved one without washing and dressing the body. This researcher recommends raising community awareness of the incumbent risk factors for Ebola infection. The proposed community awareness programs must include avoidance of physical contact with sick and dead relatives and regular washing of hands with water and soap, although the poor living conditions, including lack of water and sanitation in many areas in West Africa, do not help in terms of hand washing and disposal of wastes. [57] In the meantime, alcohol-based hand-rub solutions/sanitizers donated by the manufacturers should be distributed on a large scale, both in healthcare environments and throughout communities affected by the EVD epidemic. [38]

The study found that the second main reason for the rapid spread of EVD in Guinea, Sierra Leone and Liberia is poor healthcare delivery systems and inadequate supply of equipment to healthcare workers. $[38,16]$ The three countries have in common very weak healthcare delivery systems, lacking in both human and infrastructural resources, having only recently emerged from long periods of instability and civil strife. Many of the health workers do not have or wear appropriate protective clothing and some healthcare centers catering for EVD do not have running water for hand washing. There are many cases where reuse of needles and lack of universal precautions have resulted in hospital-acquired transmission of EVD in the affected countries. This is not surprising when healthcare spending per person each year is less than US\$100. [58] Thus, this researcher also recommends that these countries need the help of international communities to build capacity for better response to EVD spread. Some help is coming from governments and some from non-governmental organizations such as Doctors without Borders, which has provided isolation beds used to treat Ebola patients, and also from private donations to organizations such as the Disasters Emergency Committee (DEC) in the UK, which has received $£ 8$ million in donations recently. [59] This researcher would like the international community to do more to prevent EVD spreading worldwide.

The continuous low risk of EVD spreading across international borders through travel will depend of two conditions. First, the travelers must avoid direct physical contact with a sick or dead person or animal infected with EVD. Second, the international healthcare workers must work in safe environments and be provided with adequate protective equipment. This view is in line with the deposition by PHE that the continuing exponential increase in the number of cases in the affected countries and the number of travelers, including humanitarian workers returning from the affected areas, may elevate the risks of importing EVD into UK. [50]

In summary, therefore, to keep the number of cases of travel associated EVD low, particular attention needs to be given to pre-travel advice given to the travelers visiting West African countries. Many resources are available from WHO and CDC websites to inform travelers about potential health risks at their West African destination and whilst traveling. Healthcare workers who plan to work in any EVD-endemic country in West Africa should acquaint themselves with local risks, ensure availability of secure and appropriate protective equipment, and follow all the preventive measures. VFR travelers must avoid direct physical contact with a sick or dead person or animal infected with Ebola virus. All travelers must frequently wash their hands using soap and water (or alcohol hand rubs when soap is not available), as this destroys the virus. Fruits and vegetables must be washed properly and peeled before eating them. $[11,16]$ Travelers must avoid dense and crowded places where people may be infected, avoid physical contact with anyone who has symptoms, and not eat bush meat or handle dead animals or 
their raw meat. [60]

\section{Limitations of this Review}

There are three main limitations that apply to this review. First, the West African EVD outbreak is ongoing in multiple geographical locations, and no simple mixing matrix can capture the complex geographical patterns of the spread. As at the time of completing this study, September, 2014, the outbreak which began in March this year had cases reported in six countries in the region, and three in Europe and America respectively. [11, 16]

Second, the above tables reported a total of 6,808 suspected cases and 3,159 deaths resulting from the EVD outbreak in West Africa as at September 2014. However, WHO argued that the figures understate the size of the outbreak. This was attributed in part to concealment and denial of cases. In remote villages, corpses are often buried without notifying health officials and without investigating the cause of death. There are instances where epidemiologists have gone to villages and counted the numbers of fresh graves as a crude indicator of suspected cases. There are also cases where families and communities resisted reporting EVD deaths to health officials for documentation in death registers. There have also been unreported deaths at home due to closure of treatment centers and clinics, and a lack of personnel and equipment to investigate reports of death from the disease. [61] WHO was quoted as reporting that a more reliable estimate of real numbers as increased over reported cases by a factor of 1.5 in Guinea, 2 in Sierra Leone and 2.5 in Liberia, and death rate of about 70 percent of all cases. [37]

Third, the data analysis as illustrated in the above tables shows an average of 51 percent case fatality rate (CFR) for Liberia, Sierra Leone, and Guinea, considered lower than an average of the rates reported from previous outbreaks. [61] The low rate is not necessarily a feature of the infection itself. Rather, it is likely to be the result of a failure to account for delays between disease onset and final outcome. [62] WHO posited that difficulties in collecting information and the methodology used in compiling CFR may be resulting in an artificially low number. [61, 63] The low number is generated from a calculation in which the total number of deaths reported so far is divided by the total number of cases and conventionally expressed as a percentage.

As noted earlier, CFR represents a measure of the severity of the disease outbreak or risk of dying as a consequence of it. The CFR approach does not account for the delay between onset of EVD symptoms and the disease outcome (i.e. recovery or death) and generates a substantial underestimate of the actual CFR. In addition, CFR fails to take into account of infections that have yet to run their course but end in either recovery or death. Thus, if many new cases are being reported, then this will underrate the CFR. [62] A more reliable estimate can be made if the number of recoveries is also being reported [6].

Finally, given these limitations, the study has nevertheless provided useful findings, which show that both poor healthcare infrastructure and burial practices continue to exacerbate the EVD spread in West Africa and, without appropriate intervention, would kill thousands of people with the potential to spread to all parts of the world.

\section{Conclusions}

To conclude, primary reasons for the rapid spread of EVD in Guinea, Sierra Leone, and Liberia, the countries most affected by the EVD outbreak in West Africa, are poor healthcare delivery systems and local burial practices. [11, 16] Thus, this researcher recommends that these issues must be addressed to prevent the spread of EVD across international borders. Travelers to these countries must be given pre-travel advice to avoid contact with the blood and body fluids of animals or people who are sick or dead from EVD. [51] In addition, the international community must help the three countries to rebuild their healthcare infrastructure damaged by years of strife and civil wars. Otherwise, there is a likelihood of transmissibility and acceleration of EVD across international borders. This view is in line with WHO warning that any city with an international airport is at risk of an imported case of EVD and that specific cultural elements and local beliefs must be taken into account in response to the EVD outbreak. [13, 47] The recommendation is also consistent with PHE's view that the continuing exponential increase in the number of cases in the affected countries and the number of travelers, including humanitarian workers returning from the affected areas, may elevate the risks of importing EVD into UK. [50] The same would apply for other countries.

\section{REFERENCES}

[1] WHO (2014) statement on the meeting of the international health regulations emergency committee regarding the 2014 Ebola outbreak in West Africa. Geneva: World Health Organization, Aug 8, 2014.http://www.who.int/mediacentre/ news/statements/2014/ebola20140808/en/. (Accessed August 29, 2014).

[2] HPSC (2012), The Management of Haemorrhagic fevers in Ireland: Report of the Scientific Advisory of the Health Protection Surveillance Centre, www.hpsc.ie/AZ/Vectorborn e/ViralHaemorrhagicFever/Guidance/File,12936,en.pdf (Accessed May 20, 2014).

[3] WHO (2014), Ebola virus disease: background and summary, World Health Organisation, http://www.who.int/csr/don/2014_04_ebola/en/, (Accessed September 23, 2014). 
[4] NNMA (2014), Ebola virus - important information for clinicians, NSW Nurses and Midwives' Association, Monday 20th October, http://www.nswnma.asn.au/ebola-virus-important-informatio n-for-clinicians/ Accessed October 22, 2014)

[5] WHO (2014), Ebola virus disease: Fact sheet $N^{\circ} 103$, World Health Organisation, http://www.who.int/mediacentre/factsheets/fs103/en/(Access ed September 23, 2014)

[6] Rambaut, A. (2014), epidemic: Molecular Epidemiology and Evolution of Viral Pathogens, http://epidemic.bio.ed.ac.uk/e bolavirus_fatality_rate (Accessed September 23, 2014).

[7] CDC (2014) Ebola Virus Disease: Question and Answer on Transmission, Centers for Disease Control and Prevention, www.cdc.gov/vhf/ebola/transmission/qas.html, (Accessed September 23, 2014).

[8] WHO (2014); Frequently asked questions on Ebola virus disease, http://www.who.int/csr/disease/ebola/faq-ebola/en/. (Accessed September 29, 2014).

[9] CDC (2014) Ebola Virus Disease (EVD): Signs and Symptoms, Centers for Disease Control and Preventionhttp://www.cdc.gov/vhf/ebola/symptoms/index.ht $\mathrm{ml}$ ?s_cid $=\mathrm{cs} 284$ (Accessed September 23, 2014).

[10] Masson, P. R. and Pattillo, C. A (2001) "Monetary union in West Africa (ECOWAS): is it desirable and how could it be achieved?" International Monetary Fund

[11] WHO (2014), Global Alert and Response, Disease outbreak news: Ebola virus disease, World Health Organisation,http://www.who.int/csr/don/archive/disease/eb ola/en/. (Accessed September 26, 2014).

[12] WHO (2014)."Ebola Virus Disease in West Africa: The First 9 Months of the Epidemic and Forward Projections".WHO Ebola Response Team, New England Journal of Medicine.www.nejm.org/doi/full/10.1056/NEJMoa1411100 ?query=featured_home\#ref2 (Accessed September 29, 2014).

[13] WHO (2014), six months after the Ebola outbreak was declared: introduction, World Health Organisation, http://www.who.int/csr/disease/ebola/ebola-6-months/introd uction/en/ (Accessed September 28, 2014).

[14] WHO (2014), Case definition recommendations for Ebola or Marburg Virus Diseases

http://www.who.int/csr/resources/publications/ebola/ebola-c ase-definition-contact-en.pdf?ua=1(Accessed September 23, 2014).

[15] Denise, D. and Fink, S., (2014). Tracing Ebola's Breakout to an African 2-Year-Old".The New York Times. http://www.nytimes.com/2014/08/10/world/africa/tracing-eb olas-breakout-to-an-african-2-year-old.html?_r=0 (Accessed September 29, 2014).

[16] CDC (2014), Previous Updates: 2014 West Africa Outbreak, Centers for Disease Control and Prevention, http://www.cdc.gov/vhf/ebola/outbreaks/2014-west-africa/pr evious-updates.html (Accessed September 26, 2014).

[17] CDC (2014), Ebola in Liberia, Centers for Disease Control and Prevention http://wwwnc.cdc.gov/travel/notices/warning/ebola-liberia.
(Accessed September 23, 2014).

[18] CDC (2014), Ebola in Sierra Leone, Centers for Disease Control and Prevention,

wwwnc.cdc.gov/travel/notices/warning/ebola-sierra-leone (Accessed September 23, 2014).

[19] Szabo, L. (2014), CDC: Ebola outbreak in Nigeria and Senegal may be over, USA TODAY2:01 p.m. EDT September 30, http://www.usatoday.com/story/news/nation/2 014/09/30/ebola-over-in-nigeria/16473339/ (Accessed Septe mber 27, 2014).

[20] Flynn, D (2014), Guinean student is first case of Ebola confirmed in Senegal, REUTER, Reporting by Diadie Ba; Writing by Daniel Flynn; Editing by Emma Fargeand Tom Heneghan DAKAR, Fri Aug 29, 2014 2:23pm BST, http://uk.reuters.com/article/2014/08/29/us-health-ebola-sene gal-idUKKBN0GT1CD20140829 (Accessed September 25, 2014).

[21] Adjovi, L. (2014), Ebola outbreak: Senegal announces restrictions, BBC World Service Africa, 22 August at 19:23 BST, http://www.bbc.co.uk/news/world-africa-28904030. (Accessed September 23, 2014).

[22] Ba, D. and Samb, S. (2014), Ebola outbreak reaches Senegal, riots break out in Guinea, Fri Aug 29, 2014 7:28pm EDT, http://www.reuters.com/article/2014/08/29/us-health-ebola-i dUSKBN0GS1SU20140829. (Accessed September 28, 2014).

[23] WHO (2014), Countries Statistics: Guinea, World Health Organisation, http://www.who.int/countries/gin/en (Accessed September 23, 2014).

[24] WHO (2014), Countries Statistics: Liberia, World Health Organisation, http://www.who.int/countries/lbr/en/ (Accesse d September 23, 2014).

[25] WHO (2014), Countries Statistics: Sierra Leone, World Health Organisation, http://www.who.int/countries/sle/en/ (Accessed September 23, 2014).

[26] Worthington, S. A., (2014), Ebola: A Fragile Health Care System's Ripple Effects, http://www.huffingtonpost.com/samuel-a-worthington/ebola -a-fragile-healthcar_b 5871080.html (Accessed September $27,2014)$.

[27] CDC (2014), Morbidity and Mortality Weekly Report (MMWR): Ebola Virus Disease Outbreak — Nigeria, JulySeptember 2014, Centers for Disease Control and Prevention, http://www.cdc.gov/mmwr/preview/mmwrhtml/mm6339a5. htm (Accessed September 23, 2014).

[28] UNWTO (2014), tourism key to development, prosperity and well-being, World Tourism Organization UNWTO, http:/www.e nwto.org/content/r13521/fulltext.pdf. (Accessed August 28, 2014).

[29] Onuah, F. and Miles, T. (2014), Nigeria government confirms Ebola case in megacity of Lagos, ABUJA/GENEVA Fri Jul 25, 2014 3:25pm EDT,

http://www.reuters.com/article/2014/07/25/us-heath-ebola-ni geria-idUSKBN0FU1LE20140725 (Accessed September 25, 2014).

[30] Khan, N. (2014), In battling Ebola, fighting panic is as critical 
as containing virus, Algazeera Online News, http://america.aljazeera.com/articles/2014/10/16/in-battlingebolafightingpanicisascriticalascontainingvirus.html (Accessed September 24, 2014).

[31] Richens, J (2006), Sexually transmitted infections and HIV among travellers: A review, Travel Medicine and Infectious Disease, Volume 4, Issues 3-4, May-July, Pages 184-195, http://www.sciencedirect.com/science/article/pii/S14778939 0500075X (Accessed March 20, 2014).

[32] Hamlyn, E., Peer, A. and Easterbrook, P. (2007), Sexual health and HIV in travellers and expatriates, Oxford Journals, Medicine \& Health, Occupational Medicine, Volume 57, Issue 5, Pp. 313-321., http://occmed.oxfordjournals.org/cont ent/57/5/313.full. (Accessed March 20, 2014).

[33] WHO (2014) International Travel and Health, World Health Organisation, http://www.who.int/ith/updates/20140421/en/ (Accessed September 24, 2014).

[34] Ortiz, E. (2014)Man Who Died of Ebola in Nigeria Was American Citizen, NBC, News, http://www.nbcnews.com/st oryline/ebola-virus-outbreak/man-who-died-ebola-nigeria-w as-american-citizen-wife-n167546 (Accessed September 29, 2014).

[35] WHO (2014) Air travel is low-risk for Ebola transmission, World Health Organization, http://www.who.int/mediacentre/news/notes/2014/ebola-trav el/en/ (Accessed September 24, 2014).

[36] Diamond, D. (2014), Ebola Has Killed More Than 200 Doctors, Nurses, And Other Healthcare Workers Since June, http://www.forbes.com/sites/dandiamond/2014/10/15/ebolahas-already-killed-more-than-200-doctors-nurses-and-otherhealthcare-workers/ (Accessed September 27, 2014).

[37] Miles, T. (2014), WHO revises up number of health workers killed by Ebola in Sierra Leone, Reuters, GENEVA Tue Sep 23, 2014 12:07pm EDT,

http://www.reuters.com/article/2014/09/23/us-health-ebola-h ealthworkers-idUSKCN0HI1J020140923.

(Accessed September 28, 2014).

[38] WHO (2014), Ebola response roadmap situation report. World Health Organisation, http://apps.who.int/iris/bitstream/10665/137091/1/roadmapsi trep22Oct2014_eng.pdf?ua=1 (Accessed September 29, 2014).

[39] WHO (2014); UN senior leaders outline needs for global Ebola response, World Health Organisation, http://www.who.int/mediacentre/news/releases/2014/ebola-r esponse-needs/en/, (Accessed September 26, 2014).

[40] Perry, K. (2014), Ebola: Several Britons across the UK quarantined at home after returning from West Africa, http://www.telegraph.co.uk/health/healthnews/11014177/Eb ola-Welsh-national-who-returned-from-West-Africa-a-weekago-in-quarantine-at-home.html (Accessed September 20, 2014).

[41] CDC (2014), Ebola outbreak: UN's Ban Ki-moon warns against quarantining health workers, Centers for Disease Control and Prevention

http://www.cbc.ca/news/world/ebola-outbreak-un-s-ban-kimoon-warns-against-quarantining-health-workers-1.2821700 (Accessed September 25, 2014).
[42] Cornell, I. (2014), CBS New York, West Africa: Judge rejects Maine's bid to quarantine a nurse, Kaci Hickox over Ebola concerns, http://newyork.cbslocal.com/tag/west-africa/feed/ (Accessed September 29, 2014).

[43] CDC (2014), Ebola outbreak: UN's Ban Ki-moon warns against quarantining health workers, Centers for Disease Control and Prevention http://www.cbc.ca/news/world/ebola-outbreak-un-s-ban-kimoon-warns-against-quarantining-health-workers- 1.2821700 (Accessed September 20, 2014).

[44] NaTHNaC (2014), Health Professionals: Ebola virus disease: West Africa - update, The National Travel Health Network and Centre (NaTHNaC) www.nathnac.org/pro/clinical_updates/ebola_westafrica_22 0714.htm (Accessed September 28, 2014).

[45] NHS (2014),Ebola virus disease, NHS Choices, http://www.nhs.uk/conditions/ebola-virus/Pages/Ebola-virus. aspx, (Accessed September 29, 2014).

[46] Hewlett BS, Amola RP. (2003), Cultural contexts of ebola in Northern Uganda.Emerg Infect Dis., Volume 9, Number 10 - October 2003

http://wwwnc.cdc.gov/eid/article/9/10/02-0493 (March 20, 2014).

[47] WHO (1998) Infection Control for Viral Haemorrhagic Fevers in the African Health Care Setting World Health Organization,

http://www.who.int/csr/resources/publications/ebola/whoem cesr982sec1-4.pdf (Accessed March 15, 2014).

[48] Health Protection Agency (2008), Foreign travel-associated illness - a focus on those visiting friends and relatives: 2008 report,

http://www.hpa.org.uk/webc/HPAwebFile/HPAweb_C/1231 419800356, (Accessed May 20, 2014).

[49] Salit, I. E., Sano, M., Boggild, A. K., Kain, K. C. (2005) Travel patterns and risk behaviour of HIV-positive people travelling internationally, March 29, 2005 vol. 172 no. 7 doi: 10.1503/cmaj.1040877,

http://www.cmaj.ca/content/172/7/884.full (Accessed March 20, 2014).

[50] PHE (2014), Risk assessment of the Ebola outbreak in West Africa: UPDATED 20 October, Public Health England, https://www.gov.uk/government/uploads/system/uploads/att achment_data/file/365128/PHE_Risk_Assessment_Update_ 3_201014.pdf (Accessed August 22, 2014).

[51] CDC (2014), Zoonotic Disease: When Humans and Animals Intersect, Centers for Disease Control and Prevention, http://www.cdc.gov/24-7/cdcfastfacts/zoonotic.html (Accessed August 20, 2014).

[52] Dockins, P (2014),WHO: Traditional Burials Hamper Ebola Fight, August 02, $2014 \quad 11: 56 \quad$ AM, http://www.voanews.com/content/traditional-burial-practices -hamper-efforts-to-fight-ebola/1970353.html (Accessed September 28, 2014).

[53] Feldmann H, Geisbert TW (2011). Ebola haemorrhagic fever, Lancet, Volume 377, Issue 9768, 5-11 March 2011, Pages 849-862, http://www.ncbi.nlm.nih.gov/pmc/articles/PMC3406178/ (Accessed May 23, 2014). 
[54] Hoenen T, Groseth A, Feldmann H (2012).Current Ebola vaccines. Expert OpinBiolTher 12 (7): 859-72. http:/www.ncbi.nlm.nih.gov/pmc/articles/PMC3422127 (Accessed March 18, 2014).

[55] Kuhn JH, Becker S, Ebihara H, Geisbert TW, Johnson KM, Kawaoka Y, Lipkin WI, Negredo AI, Netesov SV, Nichol ST, Palacios G, Peters CJ, Tenorio A, Volchkov VE, Jahrling PB (2010). Proposal for a revised taxonomy of the family Filoviridae: classification, names of taxa and viruses, and virus abbreviations Archives of Virology 155 (12): 2083103.http:/www.ncbi.nlm.nih.gov/pmc/articles/PMC3074192, (Accessed March 20, 2014).

[56] VOA (2014), Liberian Man Infected with Ebola dies at Texas Hospital, Voice of America http://www.voanews.com/content/second-un-staffer-infected -iwth-ebola-in-liberia/2476380.html (Accessed September 20, 2014).

[57] Chatterson, K. (2014), Ebola Part 1: 2014 Ebola Hemorrhagic Fever in Western Africa, NATO Council of Canada, http://natocouncil.ca/analysing-an-outbreak-2014-ebola-hem orrhagic-fever-in-western-africa/, (Accessed August 29, 2014).

[58] Fong, J. (2014). Poverty is one big reason why Ebola is spreading so quickly http://www.vox.com/cards/ebola-factsyou-need-to-know/theres-one-word-that-explains-why-ebola -keeps-popping-up-in-africa. (Accessed August 28, 2014).

[59] DEC (2014), £6 Million raised, Disasters Emergency Committee (DEC),

http://www.dec.org.uk/appeals/ebola-crisis-appeal/\%C2\%A3 6-million-raised (Accessed September 30, 2014).

[60] NHS (2014), Travel advice for people concerned about Ebola virus disease, UK National Health Service http://www.nhs.uk/Conditions/ebola-virus/Pages/Travel.aspx (Accessed September 6, 2014).

[61] CIDRP (2014), As Ebola outbreak grows, WHO notes case-count difficulties, Center for Infectious Disease Research and Policy,http://www.cidrap.umn.edu/news-persp ective/2014/08/ebola-outbreak-grows-who-notes-case-countdifficulties, (Accessed August 26, 2014).

[62] Kucharski, A. J. and Edmund, W.J (2014), Case fatality rate for Ebola virus disease in West Africa, The Lancet, Vol. 384 No. 9950 p 1260

http://www.thelancet.com/search/results?fieldName=Author s\&searchTerm=Adam\%20J+Kucharski, (Accessed August $25,2014)$.

[63] WHO (2014) Situation assessment: Why the Ebola outbreak has been underestimated, World Health Organisation - 22 August 2014 http://www.who.int/mediacentre/news/ebola/22-august-2014 /en/ (Accessed August 24, 2014). 